\title{
Małgorzata Borkowska-Niszczota
}

Politechnika Białostocka

e-mail: m.borkowska@pb.edu.pl

\section{AKTYWNOŚĆ WLADZ SAMORZĄDOWYCH W STRUKTURACH KLASTROWYCH}

\section{ACTIVITY OF LOCAL GOVERNMENT IN CLUSTER STRUCTURES}

DOI: $10.15611 /$ pn.2017.473.06

JEL Classification: L14, L83, H83

Streszczenie: W artykule poruszono problem praktycznego członkostwa władz samorządowych w klastrach, w szczególności z branży turystycznej, działających w Polsce Wschodniej oraz pełnienia przez samorząd roli inicjatora tego typu powiązań. Prezentację wyników badań własnych poprzedził przegląd literatury. Przedstawiono teoretyczne zagadnienia dotyczące znaczenia władz publicznych w strukturach klastrowych, zwłaszcza ich roli w procesie powstawania i dalszym rozwoju i funkcjonowaniu tego typu powiązań sieciowych. Ukazano także wyniki wcześniejszych badań dotyczących analizowanej problematyki. Jako metody badawcze zastosowano: metodę desk research oraz badania literaturowe. Przeprowadzone badania wskazują na potrzebę większego zaangażowania władz publicznych w problemy rozwoju klastrów, poprzez bezpośredni ich udział w strukturach, obok przedstawicieli biznesu, instytucji okołobiznesowych i ośrodków naukowo-badawczych.

Słowa kluczowe: klastry turystyczne, władze samorządowe, inicjator klastra, rozwój klastrów, instrumenty wsparcia.

Summary: The article addresses the issue of practical membership of local authorities in clusters, in particular in the tourism industry operating in Eastern Poland, and the issue of the local government acting as an initiator of this type of relationships. The presentation of the results of research was preceded by a review of literature. It presents the theoretical issues concerning the importance of public authorities in cluster structures, especially their role in the formation and further development and functioning of this type of network connections. Previous results of other research on the issue were also shown. The research methods used were: the desk research method and literature studies. The study indicates the need for greater involvement of the public authorities in the problems of the development of clusters, through their direct participation in the structures, in addition to the representatives of business, business support institutions, and research centers.

Keywords: tourism clusters, local authorities, initiator of the cluster, cluster development, support instruments. 


\section{Wstęp}

Jednym z warunków rozwoju inteligentnego, czyli rozwoju gospodarki opartej na wiedzy i innowacji oraz rozwoju zrównoważonego sprzyjającego włączeniu społecznemu, jest rozwój nowoczesnych i innowacyjnych inicjatyw klastrowych. Rozwój klastrów nie jest możliwy bez zainteresowania tymi strukturami władz publicznych oraz ich aktywnego zaangażowania i wsparcia. Większość menedżerów firm zrzeszonych w klastrach działających w Unii Europejskiej jest zdania, iż władze odgrywają ważną, jeśli nie fundamentalną rolę we wspieraniu klastrów [Kaźmierski 2012, s. 15]. Praktyka pokazuje, iż władze samorządowe poza tworzeniem warunków do powstawania klastrów mogą występować w roli ich inicjatora, przyczyniając się do rozwoju nowych struktur. Przykładem klastra zainicjowanego przez władze samorządowe był Bieszczadzki transgraniczny klaster turystyczny. W literaturze przedmiotu panuje przekonanie, że władze publiczne nie powinny pełnić funkcji przywódczej (lidera) klastra, na co zwrócono uwagę w części teoretycznej. Władze regionalne i lokalne, wykorzystując różnego rodzaju narzędzia, mogą wspierać rozwój zainicjowanych już struktur. Nie bez znaczenia jest udział władz w strukturach klastrowych jako jednego z głównych podmiotów, obok przedstawicieli biznesu i instytucji okołobiznesowych oraz ośrodków naukowo-badawczych.

$\mathrm{Na}$ świecie uruchomiono dotąd setki inicjatyw klastrowych w różnych sektorach, jednak wiedza o tych inicjatywach, ich strukturze oraz sposobach zarządzania ich rozwojem jest zaskakująco mała [Kaźmierski 2011, s. 247-248].

Celem głównym niniejszego artykułu jest ukazanie udziału władz samorządowych w klastrach turystycznych Polski Wschodniej oraz ich zaangażowania w inicjowanie struktur. Dla realizacji powyższego celu wykorzystano metodę badań ze źródeł wtórnych desk research. Prezentację wyników badań własnych poprzedził przegląd literatury. W oparciu o studia literaturowe przedstawiono teoretyczne zagadnienia dotyczące znaczenia władz publicznych w strukturach klastrowych, zwłaszcza ich roli w procesie powstawania i dalszym rozwoju i funkcjonowaniu tego typu powiązań sieciowych. Ukazano także wyniki wcześniejszych badań związanych z uczestnictwem sektora publicznego w strukturach klastrowych jako członek lub inicjujący je podmiot, które były elementem szerszych obszarów badawczych oraz odnosily się do struktur zarówno o charakterze turystycznym, jak i przemysłowym.

\section{Przegląd literatury}

\subsection{Wspomaganie rozwoju i funkcjonowania klastrów przez władze samorządowe}

W turystyce funkcjonuje wiele różnych struktur sieciowych. A. Rapacz i D. Jaremen wyszczególniają m.in. franchising, outsourcing, alians strategiczny, stowarzyszenie handlowe, Lokalne i Regionalne Organizacje Turystyczne, Lokalne Grupy 
Działania, sieci tworzone w formule partnerstwa publiczno-prywatnego. Wskazują także na koncepcję klastrów jako szczególny przypadek struktur sieciowych, w których przenikają się relacje konkurencyjne i kooperacyjne [Rapacz, Jaremen 2016, s. 128-132]. Klastry to geograficzne skupiska wzajemnie powiązanych firm, wyspecjalizowanych dostawców, jednostek świadczących usługi, firm działających w pokrewnych sektorach i związanych z nimi instytucji w poszczególnych dziedzinach, konkurujących z sobą, ale także współpracujących [Porter 2001, s. 246]. Powstają one w różnych gałęziach gospodarki, m.in. w gospodarce turystycznej. M. Kachniewska określa klaster turystyczny jako ,aktywną sieć wytwórców produktów turystycznych, wspierających ich przedsiębiorstw innych branż, organizacji turystycznych, władz lokalnych i podmiotów samorządowych, instytucji otoczenia biznesu, zaplecza edukacyjno-eksperckiego (uczelnie, instytucje B+R), współpracujących ze sobą w ramach określonej marki (markowego produktu turystycznego) i jednocześnie konkurujących ze sobą jakością, innowacyjnością i unikatowością oferowanych usług" [www.slideshare]. Współdziałanie w klastrze obejmuje związki o charakterze pionowym (integracja między podmiotami łańcucha wartości), jak i poziomym (integracja pomiędzy podmiotami konkurencyjnymi), tworząc relacje kooperencyjne [Januszewska, Nawrocka 2008, s. 288]. Ten typ sieci cechuje się najniższym stopniem formalizacji, dużą zmiennością członkostwa i dynamiką relacji. Podmioty działające $w$ ramach tej struktury są niezależne, reprezentują różne dziedziny działalności, sektory oraz branże gospodarki, z tym że liczebną przewagę mają przedsiębiorcy. Partnerów współpracy łączy tożsamość lokalizacji, wspólne cele i wizja większych korzyści niż wynikające z samodzielnego działania. Są one postrzegane jako źródło korzyści nie tylko dla ich uczestników, ale również otoczenia. W rezultacie kooperacji, wymiany know-how, informacji, pomnażania wiedzy i kapitału społecznego przedsiębiorstwa turystyczne stają się bardziej innowacyjne, wyspecjalizowane i konkurencyjne. Wyższy stopień innowacyjności prowadzi do kreowania wyższej wartości dla klientów i oferty na miarę oczekiwań współczesnych turystów [Rapacz, Jaremen 2016, s. 131].

W literaturze często pojawia się pogląd, że klastry są porównywalną formą organizacyjną, jak ROT lub LOT. M. Januszewska i E. Nawrocka [2008, s. 290-292] dostrzegają jednak podobieństwa w ich funkcjonowaniu (biorąc pod uwagę zasięg geograficzny działania, cele funkcjonowania, formę organizacyjno-prawną, zasady członkostwa, źródła finansowania, założenia w tworzeniu marki produktu i wizerunku obszaru, perspektywę czasową), ale też istotne różnice pomiędzy tymi instytucjami (ze względu na proces tworzenia, rodzaje podmiotów przynależących, strukturę członkowską, podmiot inicjujący i koordynujący, znaczenie jednostki badawczej i innowacji w działalności, mierniki rozwoju). Zauważają, iż możliwe i celowe jest przekształcenie ROT/LOT w klastry turystyczne, gdy członkowie wykażą się wysoką przedsiębiorczością i innowacyjnością, niskim poziomem biurokracji, niewielkim stopniem sformalizowania, większą skłonnością do transferu wiedzy, osłabieniem wpływu czynników politycznych na ich funkcjonowanie. Działania członków 
ROT/LOT w formule klastra muszą przyczynić się do powstania zintegrowanego, innowacyjnego produktu turystycznego regionu i w konsekwencji pozytywnie wpływać na konkurencyjność regionu. W. Fedyk i M. Kachniewska [2016] podjęli próbę opracowania modelu funkcjonowania ROT w formule klastra turystycznego.

W klastrach mamy do czynienia z łączeniem potencjałów sektora prywatnego, badawczo-rozwojowego oraz publicznego. Każdy z podmiotów ma do spełnienia w ramach klastra określone zadania. Sektor publiczny jako istotny element struktur klastrowych powinien prowadzić taką politykę, która nie będzie szkodliwa dla rozwoju klastrów, firm w nim działających oraz całego obszaru. Musi się nauczyć odpowiedniej aktywności w klastrach, jednocześnie nie przejmując odpowiedzialności za wszystkie działania [Sovell i in. 2006]. Mogą to być jedynie działania organizacyjno-promocyjne oraz finansowo-ekonomiczne. Potrzeba takiej pomocy oraz aktywnego włączania się administracji publicznej w procesy powstawania i umacniania inicjatyw o charakterze klastrowym wynika m.in. z raportu A. Lisowskiej i S. Rubisza [2011], jaki powstał w oparciu o badania przedstawicieli administracji w województwie opolskim.

Przedmiotem polityki na poziomie miast i regionów powinno być wspieranie organizacji klastrowych bądź innych podmiotów prawnych zajmujących się zarządzaniem w zakresie klastra, w tym opracowaniem zasad uczestnictwa i dostępu do wspólnej infrastruktury bądź działań. Utworzenie organizacji klastrowej powinno być wspierane przez władze przez pogłębienie współpracy między środowiskami gospodarki, administracji i nauki. Władze regionalne i lokalne, będąc gospodarzem danego terenu, powinny stwarzać jak najlepsze warunki do współpracy zrzeszających się podmiotów, stymulując kontakty między nimi. Jest to rola wychodząca poza ich prawne kompetencje, ale bardzo istotna [Kaźmierski 2014, s. 46-51].

Działania ukierunkowane na wspomaganie funkcjonowania klastrów oraz ich rozwój powinny być odpowiednio zaplanowane. Tylko wtedy mamy większą pewność, że będą one zrealizowane [Kraska 2012, s. 95]. W związku z powyższym wspieranie rozwoju klastrów, szczególnie o największym potencjale konkurencyjnym i kluczowym znaczeniu dla gospodarki regionu, powinno być założeniem strategicznych dokumentów programowych (strategii rozwoju, regionalnych strategii innowacji). Powinno się w nich wskazywać na sposoby pobudzenia i rozwoju współpracy sieciowej. Może też powstać odrębne opracowanie, w sposób kompleksowy prezentujące politykę klastrową władz. Przykładem są „Kierunki rozwoju województwa podkarpackiego w oparciu o klastry", w którym przewidziano m.in. system wsparcia klastrów, system edukacji i informacji w zakresie klasteringu, stworzenie dogodnych warunków inwestycyjnych dla ich rozwoju oraz system promocji. Działania na rzecz struktur klastrowych powinny być także elementem planów rozwoju lokalnego czy strategii rozwoju gmin. W tabeli 1 zaprezentowano przykładowe formy wsparcia klastrów przez władze samorządowe.

Według Portera [2001] zalecane jest wręcz działanie czynnika publicznego w kreowaniu i stymulowaniu klastrów. Także zdaniem Kaźmierskiego celowość an- 
Tabela 1. Działalność władz samorządowych na rzecz klastrów

\begin{tabular}{|c|c|c|}
\hline & $\begin{array}{l}\text { rozwijanie umiejętności i kompetencji } \\
\text { zasobów ludzkich, } \\
\text { wpływanie na rozwój szkolnictwa i zmiany } \\
\text { w systemie edukacyjnym, } \\
\text { stymulowanie przepływu wiedzy oraz } \\
\text { redukowanie zakłóceń w przepływie } \\
\text { informacji i koordynacji działań, } \\
\text { zwiększenie masy krytycznej podmiotów } \\
\text { gospodarczych, } \\
\text { wsparcie promocji przedsiębiorstw oraz idei } \\
\text { wspólnego marketingu całego klastra, } \\
\text { wzmocnienie interakcji biznesowych, } \\
\text { wspieranie rozwoju instytucji naukowych, } \\
\text { badawczych, szkoleniowych oraz sieci } \\
\text { współpracy między nimi, } \\
\text { tworzenie platform współpracy firm } \\
\text { i instytucji naukowo-badawczych, } \\
\text { tworzenie platform wymiany wiedzy } \\
\text { i doświadczeń między klastrami. }\end{array}$ & $\begin{array}{l}\text { - zwiększenie nakładów na prace badawczo- } \\
\text {-rozwojowe i działania innowacyjne, } \\
\text { - usprawnienie otoczenia biznesu, } \\
\text { - odpowiednie inwestycje w infrastrukturę, } \\
\text { skrócenie drogi biurokratycznej w zakresie } \\
\text { otwierania nowych firm czy pozyskiwania } \\
\text { publicznych środków wsparcia, } \\
\text { - szkolenia związane z ideą klasteringu, } \\
\text { - działania promocyjne całego regionu, branż, } \\
\text { w których działają klastry, } \\
\text { - tworzenie komórek organizacyjnych ds. } \\
\text { klastrów w urzędach, } \\
\text { - tworzenie jednostek wspierających inkubację } \\
\text { klastrów, } \\
\text { - finansowanie działań z programów } \\
\text { publicznych, } \\
\text { - uwzględnienie klastrów w strategicznych } \\
\text { dokumentach programowych oraz } \\
\text { odpowiednich instrumentów wsparcia. }\end{array}$ \\
\hline
\end{tabular}

Źródło: [Palmen, Baron 2008, s. 37-39; Mikołajczyk i in. 2009, s. 27; Leśniewski 2012, s. 72; Putkiewicz, Sokołowska 2006, s. 229].

gażowania się administracji regionalnej i lokalnej w rozwój inicjatyw klastrowych jest bezsporna. Stosunek władz do rozwoju klastrów powinien koncentrować się na czterech elementach [Raines 2006, s. 9-10, za: Kaźmierski 2011, s. 252]:

- na wspieraniu sieci, a nie pojedynczych przedsiębiorstw;

- wspierane powinny być jedynie wybrane sieci przedsiębiorstw;

- powinny to być działania kładące nacisk na wzmacnianie procesów innowacyjnych i procesów uczenia się między podmiotami działającymi w klastrze;

- o ile wspieranie klastrów może być realizowane na wszystkich poziomach władzy publicznej, od regionalnego (lokalnego) do międzynarodowego, o tyle dominujące znaczenie mają działania podejmowane przez podmioty działające na poziomie regionalnym czy lokalnym.

Władze regionalne powinny opracować zasady wspierania klastrów, które określą nie tylko sposoby wsparcia, ale i kryteria dostępu do nich. Zapewniłoby to równy dostęp do środków publicznych, ale przede wszystkim ukierunkowało aktywność klastrów na działania zgodne z prowadzoną polityką regionalną. Ważne jest zaangażowanie klastrów w opracowywanie wytycznych regionalnej polityki klastrowej. Władze regionalne powinny także traktować klastry jako partnera w procesie wyznaczania inteligentnych specjalizacji i wdrażania regionalnych strategii innowacji [Plawgo 2014, s. 191]. W ramach prowadzonej polityki rozwoju klastrów władze samorządowe inaczej powinny traktować klastry duże, reprezentujące branże nastawione na rynki zewnętrzne, a inaczej małe, obsługujące rynki lokalne (regionalne). 
Instrumenty wsparcia powinny uwzględniać specyfikę klastrów i być dostosowane do stopnia ich rozwoju. Dla obu tych grup należy przewidywać różne formy i intensywność wsparcia [Plawgo 2014, s. 188].

Władze samorządowe powinny dostrzegać we wspieraniu klastrów szansę na rozwój lokalnej gospodarki, np. poprzez przyciągnięcie nowych firm do regionu, powstanie nowych miejsc pracy, a także dobry sposób na kształtowanie i wzmacnianie marki danego miasta lub regionu jako centrum kompetencji w danej specjalizacji [Kaźmierski 2014, s. 51]. Z tych i wielu innych korzyści wynika konieczność tworzenia uwarunkowań dla rozwoju klastrów. W związku z powyższym ważne jest powołanie instytucji regionalnej odpowiedzialnej za rozwój gospodarczy, w tym wspieranie działalności podejmowanych przez klastry i na rzecz klastrów [Lisowska, Rubisz 2011, s. 52].

Porter podkreślał, że zdecydowanie partner publiczny nie powinien być liderem działalności klastra, zalecając jednakże jego udział w rozwoju klastrów. Według niego samorząd może tworzyć warunki organizacyjne i klimat dla podejmowanych inicjatyw biznesowych i współpracy [Nowakowska (red.) 2015, s. 171]. Do prowadzenia klastra niezbędne jest odpowiednie przygotowanie oraz umiejętności związane $\mathrm{z}$ rozwiązywaniem w klastrze swoistych problemów. Zarządzający klastrem powinien posiadać zarówno wiedzę merytoryczną, jak i umiejętności praktyczne [Lisowska, Rubisz 2011, s. 33]. Badania przeprowadzone przez J. Kaźmierskiego dowodzą, iż najbardziej efektywnymi strukturami są te, w których funkcję lidera klastra pełnią sami przedsiębiorcy. Jego zdaniem optymalne jest też zawiązywanie współpracy klastrowej przez grupę podmiotów, a dopiero później angażowanie do niej administracji publicznej [Kaźmierski 2011, s. 251].

Za bezpośrednim zaangażowaniem władz publicznych w inicjatywy klastrowe, zwłaszcza turystyczne, przemawia wiele argumentów. Działania jednostek samorządu terytorialnego są decydujące $\mathrm{w}$ tworzeniu lokalnych i regionalnych produktów turystycznych, łączących świadczenia oferentów bezpośredniej gospodarki turystycznej oraz usług paraturystycznych. To od nich zależy struktura i jakość oferty na administrowanym obszarze [Panasiuk 2016]. Badania dowodzą, że polskie przedsiębiorstwa turystyczne potrzebują w sieci wyraźnego uczestnictwa władz samorządowych. Udział władz daje gwarancję stabilności układu powiązań oraz często decyduje o podjęciu decyzji o przystąpieniu do klastra. Liczne uczestnictwo w klastrze jednostek samorządu terytorialnego jest jego siłą i kluczowym czynnikiem sukcesu [Staszewska 2009]. Współuczestnictwo władz w klastrze świadczy o otwartości na współpracę i podkreśla znaczenie budowania relacji z biznesem i instytucjami okołobiznesowymi [Nowakowska (red.) 2015]. Bezpośrednie zaangażowanie samorządu może skutkować większą koordynacją strategii klastra ze strategią rozwoju lokalnego czy regionalnego. Niestety, możemy mieć do czynienia też z niebezpieczeństwem nadmiernej ingerencji władz, forsowaniem przez władze własnej koncepcji rozwojowej. Zbyt duża aktywność samorządów może skutkować brakiem prawdziwego zaangażowania innych podmiotów. Tylko równomierne zaan- 
gażowanie współdziałających podmiotów, w tym władz samorządowych, sprawi, że idea klastra będzie interesująca i perspektywiczna dla przedsiębiorstw świadczących usługi turystyczne [Zajadacz, Śniadek 2010].

\subsection{Udział władz samorządowych w klastrach różnych branż oraz w ich powstawaniu w świetle dotychczasowych badań}

W literaturze przedmiotu odnajdujemy nieliczne wyniki badań dotyczące udziału władz samorządowych w strukturach klastrowych oraz ich inicjowaniu. Dotychczasowe badania prowadzono $\mathrm{w}$ jednostkach samorządu terytorialnego oraz badając strukturę klastrów przeważnie pochodzących z różnych branż.

W 2011 r. przeprowadzono badania ankietowe w 102 gminach województwa świętokrzyskiego mające na celu określenie roli władz w tworzeniu i funkcjonowaniu klastrów, w tym z branży turystycznej. Wyniki otrzymane z $46 \%$ gmin pokazały:

- znikomy udział ich w powstawaniu - inicjowaniu klastrów (4\%);

- niewielki udział gmin w strukturach klastrowych jako członek (22\%).

Gminy uczestniczące w badaniu były członkami dwóch klastrów, w tym jednego turystycznego. Działania na rzecz rozwoju klastrów w swoich planach rozwoju lokalnego i strategiach rozwoju uwzględniało tylko 7,7\% gmin. Były to równocześnie gminy będące ich członkami. Faktyczne działania wspierające klastry prowadziło niespełna $27 \%$ badanych gmin. Koncentrowały się one przeważnie na promocji idei współpracy i klasteringu [Kraska 2012, s. 93-95].

W trakcie badań przeprowadzonych wśród członków 35 klastrów różnych branż (z wyjątkiem turystycznych) w ramach inicjatywy Polskiej Agencji Rozwoju Przedsiębiorczości „Benchmarking klastrów w Polsce - edycja 2014” próbowano ocenić ich strukturę podmiotową. Jedynie 30\% badanych wskazywało, iż struktura klastrów jest właściwa. Brak w strukturze podmiotowej klastrów jednostek samorządu terytorialnego dostrzegało blisko $14 \%$ respondentów. Zdaniem sporej grupy, bo aż $20 \%$ członków, warto zwiększyć liczebność przedsiębiorstw. Zwracano także uwagę na braki innych podmiotów, w tym jednostek naukowych i instytucji otoczenia biznesu (po 15\%). Najmniejsza część badanych (7,6\%) opowiedziała się za zwiększeniem liczby organizacji pozarządowych. $Z$ badań wynika, iż na 35 klastrów, które były przedmiotem analizy, jedynie 5 powstało wskutek działań ze strony sektora publicznego w ramach inicjatywy odgórnej [Plawgo 2014, s. 23-24].

Podobnie przedstawiały się badania z wcześniejszej edycji - w roku 2012. Wynika z nich, iż samorząd terytorialny był samodzielnym inicjatorem 4 z 35 klastrów poddanych badaniom (w którym uczestniczył jeden klaster z branży turystycznej). $\mathrm{W}$ raporcie $\mathrm{z}$ badań, przedstawiając udział poszczególnych członków w strukturze klastrów, władze samorządowe zakwalifikowane zostały jako inne podmioty. Podmioty publiczne wraz z osobami fizycznymi jako inne podmioty stanowiły zaledwie 10\% wszystkich podmiotów w klastrach [Hołub-Iwan 2012, s. 24-25]. 


\section{Metodyka}

W celu określenia udziału władz samorządowych w strukturach klastrowych o charakterze turystycznym Polski Wschodniej oraz ich aktywności jako inicjatorów współpracy wykorzystano metodę badań ze źródeł wtórnych (desk research). Głównym źródłem informacji były strony internetowe struktur klastrowych lub ich koordynatorów oraz opracowanie naukowe Romana i Zawadki [2010]. Zanim przystąpiono do analizy struktur, dokonano identyfikacji klastrów działających w branży turystycznej w pięciu województwach makroregionu Polski Wschodniej. Przy identyfikacji klastrów korzystano z katalogów klastrów dla poszczególnych województw opracowanych przez Polską Agencję Rozwoju Przedsiębiorczości oraz Mapy klastrów w Polsce - bazy podstawowych danych na temat krajowych klastrów, prowadzonej przez PARP. Badania przeprowadzono w 2015 r.

\section{Wyniki badań - udział władz samorządowych w turystycznych strukturach klastrowych Polski Wschodniej oraz w ich powstawaniu}

Badania pozwoliły zidentyfikować 16 klastrów turystycznych funkcjonujących w Polsce Wschodniej, obejmującej swym zasięgiem województwa: podlaskie, warmińsko-mazurskie, podkarpackie, świętokrzyskie oraz lubelskie.

Struktura istniejących klastrów jest bardzo zróżnicowana (zob. rys. 1).

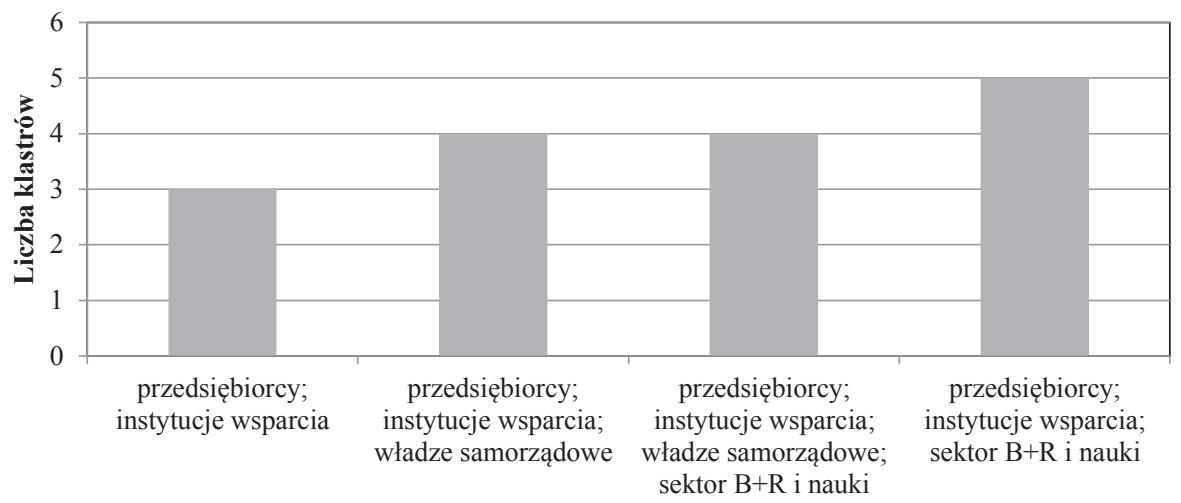

Rys. 1. Podział liczbowy klastrów turystycznych ze względu na strukturę członków

Źródło: opracowanie własne.

Pełną strukturę podmiotową charakterystyczną dla klastrów posiadają jedynie 4 klastry (25\% badanych struktur). Ponadto analiza podmiotów wchodzących w skład klastrów wykazała, iż spośród podstawowych 4 grup instytucji składających 
się na modelowy klaster (tj. przedsiębiorstwa, instytucje wsparcia, podmioty sektora nauki i $\mathrm{B}+\mathrm{R}$, władze samorządowe) dominują przedsiębiorstwa. Podmioty te mają swój udział w każdej ze struktur.

Władze samorządowe powinny być jednym z podmiotów uczestniczących na zasadzie członkostwa w klastrach turystycznych. Biorąc pod uwagę klastry turystyczne Polski Wschodniej, zauważa się obecność władz w 8 strukturach, czyli w 50\% analizowanych przypadków. Dotyczy to wspomnianych wcześniej 4 klastrów, w których udział mają przedstawiciele wszystkich sektorów. W kolejnych 4 wśród członków klastrów brakuje jedynie przedstawicieli sektora nauki i badawczo-rozwojowego, natomiast swój udział - obok władz samorządowych - mają przedsiębiorcy oraz instytucje wsparcia. W pozostałych 8 przypadkach klastrów turystycznych brakuje władz jako oficjalnego członka w strukturze. Niemniej w połowie z nich (4 klastrach) dostrzega się współpracę z sektorem publicznym jako partnerem zewnętrznym.

Władze samorządowe mogą odegrać istotną rolę w inicjowaniu struktur klastrowych, zwłaszcza w przypadku braku inicjatyw sektora prywatnego lub pozarządowego. Przeprowadzona analiza form inicjowania działalności klastrów turystycznych Polski Wschodniej wskazuje na znikomy udział władz jako przedstawicieli sektora publicznego. Udział ten zobrazowano na wykresie prezentującym typy inicjatyw powołania klastrów turystycznych w Polsce Wschodniej (rys. 2).

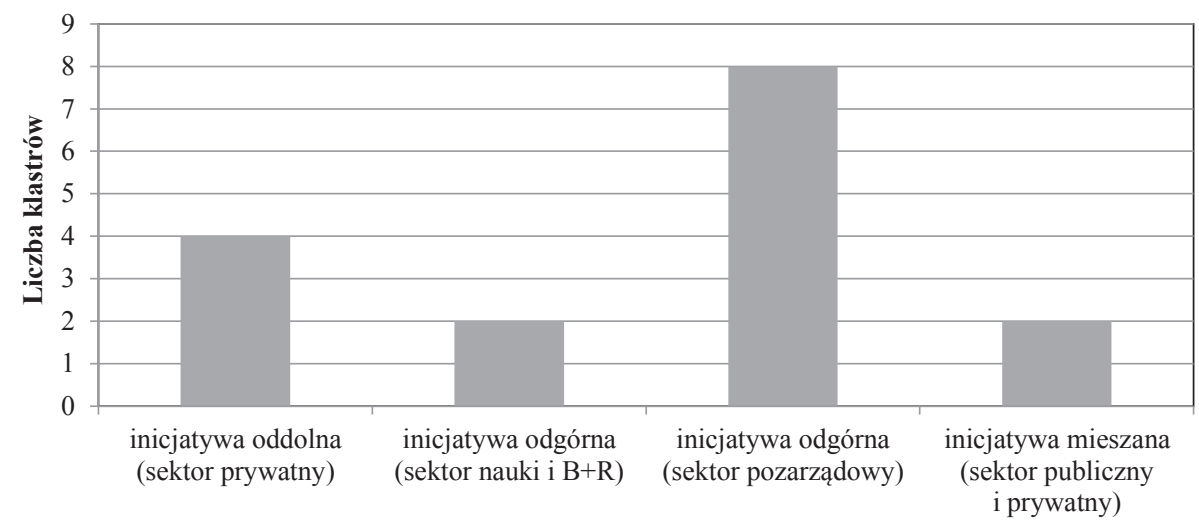

Rys. 2. Podział liczbowy klastrów turystycznych ze względu na typ inicjowania działalności Źródło: opracowanie własne.

Sektor publiczny wspólnie z prywatnym (w ramach inicjatywy mieszanej) był inicjatorem 2 struktur klastrowych. Największa liczba klastrów (10 struktur) powstała w ramach inicjatywy odgórnej. Inicjatorem $8 \mathrm{z}$ nich byli przedstawiciele sektora pozarządowego, 2 - przedstawiciele nauki. $\mathrm{Z}$ inicjatywy przedstawicieli biznesu powstały 4 klastry. 


\section{Wnioski z badań}

Dotychczasowe działania PARP na rzecz promocji klastrów i klasteringu, znaczenia gospodarki opartej na klastrach, a zwłaszcza roli urzędników w ich inicjowaniu i rozwoju powinny być kontynuowane. Jak pokazuje praktyka, wciąż potrzebne jest większe zaangażowanie samorządów w problemy rozwoju i działalność klastrów. Może się to odbywać poprzez ich bezpośredni udział w strukturach klastrowych.

Zarówno badania literaturowe, jak i własne wykazały znikomy udział podmiotów publicznych jako członków klastrów oraz ich inicjatorów. Braki w strukturze klastrowej jednostek samorządu terytorialnego dotyczą klastrów różnych branż, w tym z branży turystycznej. Klastry rzadko powstają w ramach inicjatywy odgórnej ze strony samego samorządu terytorialnego. W klastrach turystycznych samorządy terytorialne, podejmując się powołania struktury klastrowej, robią to we współpracy z sektorem prywatnym, w ramach inicjatywy mieszanej.

\section{Zakończenie}

Wszystkie struktury klastrowe, w szczególności z branży turystycznej, powinny powstawać i rozwijać się dzięki większej aktywności i bezpośredniemu zaangażowaniu władz publicznych. Niezwykle ważne jest wsparcie merytoryczne, organizacyjne, promocyjne i finansowe.

Zdaniem Panasiuka jednostki samorządu terytorialnego jako podmioty reprezentujące destynacje turystyczne na rynku turystycznym powinny odgrywać podstawową rolę w partnerstwie i współpracy w obszarze turystycznym. Kompleksowe współdziałanie podmiotów reprezentujących podaż na rynku turystycznym, w tym samorządu, jest podstawą tworzenia oferty turystycznej [Panasiuk 2016].

W celu rzeczywistego zaangażowania samorządów powinno się prowadzić w większym zakresie działania upowszechniające wiedzę na temat klastrów oraz wynikające z nich korzyści, nie tylko wśród przedsiębiorców, ale także władz samorządowych jako potencjalnych ich członków. Władze powinny dysponować wiedzą na temat możliwych działań, jakie mogłyby podejmować na rzecz rozwoju i wzmacniania klastrów. Należy także eliminować bariery informacyjne na linii administracja-przedsiębiorcy. Lisowska i Rubisz [2011] proponują regionalne portale informacyjne służące jako pas transmisyjny między nimi oraz będące zaczątkiem współpracy między tymi dwoma istotnymi elementami w strukturze nowych klastrów.

\section{Literatura}

Fedyk W., Kachniewska M., 2016, Uwarunkowania skuteczności funkcjonowania regionalnych organizacji turystycznych w Polsce w formule klastrów turystycznych, Ekonomiczne Problemy Turystyki, nr 1 (33), Szczecin.

Hołub-Iwan J. (red.), 2012, Benchmarking klastrów w Polsce-edycja 2014. Raport z badania, Agencja Wydawnicza Ekopress, Warszawa. 
Januszewska M., Nawrocka E., 2008, Pobudzanie przedsiębiorczości lokalnej i innowacyjności a konkurencyjność obszaru recepcji turystycznej, [w:] Gołembski G. (red.), Turystyka jako czynnik wzrostu konkurencyjności regionów w dobie globalizacji, Wydawnictwo AE w Poznaniu, Poznań.

Kaźmierski J., 2012, Rozwój i zarządzanie strukturami klastrowymi w regionie, Wydawnictwo UŁ, Łódź.

Kaźmierski J., 2011, Wspieranie rozwoju struktur klastrowych - modele, instrumenty, bariery, Acta Universitatis Lodziensis, Folia Oeconomica, nr 261.

Kaźmierski J., 2014, Wspieranie rozwoju struktur klastrowych przez władze samorzadowe miasta i regionu, Problemy Rozwoju Miast, $\mathrm{nr} 1$.

Kraska E., 2012, Wpływ władz samorządowych na tworzenie i funkcjonowanie klastrów na przykładzie gmin województwa świętokrzyskiego, Zarządzanie i Finanse, red. Antonowicz A., vol. 10, nr 1 (2).

Leśniewski M., 2012, Koncepcja klastra w ksztattowaniu rozwoju regionalnego - ujęcie teoretyczne. Zarys problemu, Acta Scientifica Acta Demiae Ostorviensis, Sectio A, nr 1.

Lisowska A., Rubisz S., 2011, Sektor instytucji publicznych a rozwój klastrów w województwie opolskim, t. 6, Wydawnictwo Instytut Śląski, Opole.

Mikołajczyk B., Kurczewska A., Fila J., 2009, Klastry na świecie. Studia przypadków, Wydawnictwo Difin, Warszawa.

Nowakowska A. (red.), 2015, Nowoczesne metody zarządzania rozwojem lokalnym i regionalnym, Wydawnictwo UŁ, Łódź.

Palmen L., Baron M., 2008, Przewodnik dla animatorów inicjatyw klastrowych w Polsce, Warszawa.

Panasiuk A., 2016, Wspótpraca podmiotów w destynacji turystycznej, [w:] Młynarczyk Z., Zajadacz A. (red.), Uwarunkowania i plany rozwoju turystyki. Społeczno-ekonomiczne problemy rozwoju turystyki, Turystyka i Rekreacja, Studia i Prace, nr 16, Bogucki Wydawnictwo Naukowe, Poznań.

Plawgo B., 2014, Benchmarking klastrów w Polsce - edycja 2014. Raport z badania, Polska Agencja Rozwoju przedsiębiorczości, Warszawa.

Porter M.E, 2001, Porter o konkurencji, PWE, Warszawa.

Putkiewicz W., Sokołowska D., 2006, Region a klastry, [w:] Bojar E. (red.), Klastry jako narzędzia lokalnego i regionalnego rozwoju gospodarczego, Wydawnictwo Politechniki Lubelskiej, Lublin.

Raines P., 2006, The Cluster Approach and the Dynamics of Regional Policy-Making, Regional and Industry Policy Research, no. 47, University of Strathclyde and Glasgow.

Rapacz A., Jaremen D., 2016, Struktury sieciowe w turystyce i możliwości ich rozwoju w Kotlinie Jeleniogórskiej, [w:] Młynarczyk Z., Zajadacz A. (red.), Uwarunkowania i plany rozwoju turystyki. Społeczno-ekonomiczne problem rozwoju turystyki, Turystyka I Rekreacja - Studia i Prace, nr 16, Bogucki Wydawnictwo Naukowe, Poznań

Roman M., Zawadka J., 2010, Klaster Okopski jako forma innowacyjnych działań w agroturystyce, [w:] Pangsy-Kania S., Szczodrowski G. (red.), Gospodarka polska po 20 latach transformacji: osiagnięcia, problemy $i$ wyzwania, Wydawnictwo Instytut Wiedzy i Innowacji.

Sovell O., Lindgvist G., Ketels Ch., 2006, Zielona Ksiega Inicjatyw Klastrowych. Inicjatywy klastrowe w gospodarkach rozwijajacych się i w fazie transformacji, PARP, Center For Strategy and Compatitiveness.

Staszewska J., 2009, Klaster perspektywą dla przedsiębiorców na polskim rynku turystycznym, Wyd. Difin, Warszawa.

www.slideshare.net.

Zajadacz A., Śniadek J., 2010, Klaster turystyczny jako forma wspótpracy podmiotów gospodarki turystycznej w powiecie leszczyńskim, w: Gospodarka turystyczna w XXI wieku, Zeszyty Naukowe, nr 19, Wydawnictwo Wyższej Szkoły Handlu i Usług w Poznaniu, Poznań.

Badania zostały zrealizowane $\mathrm{w}$ ramach pracy $\mathrm{S} / \mathrm{WZ} / 5 / 2015$ i sfinansowane ze środków na naukę MNiSW. 